\title{
Shorter, warmer winters may inhibit production of ephyrae in a population of the moon jellyfish Aurelia aurita
}

\author{
Alexandra Loveridge $\mathbb{( D} \cdot$ Cathy H. Lucas $\mathbb{B} \cdot$ Kylie A. Pitt $\mathbb{B}$
}

Received: 1 July 2020/Revised: 19 November 2020/ Accepted: 26 November 2020/Published online: 14 December 2020

(C) The Author(s) 2020

\begin{abstract}
Scyphozoan jellyfish blooms display high interannual variability in terms of timing of appearance and size of the bloom. To understand the causes of this variability, the conditions experienced by the polyps prior to the production of ephyrae in the spring were examined. Polyps reared from planula larvae of Aurelia aurita medusae collected from southern England $\left(50^{\circ} 49^{\prime} 58.8 ;-1^{\circ} 05^{\prime} 36.9\right)$ were incubated under orthogonal combinations of temperature $(4,7$, $10^{\circ} \mathrm{C}$ ) and duration (2, 4, 6, 8 weeks), representing the range of winter conditions in that region, before experiencing an increase to $13{ }^{\circ} \mathrm{C}$. Timing and success of strobilation were recorded. No significant production of ephyrae was observed in any of the 2- and 4-week incubations, or in any $10{ }^{\circ} \mathrm{C}$ incubation. Time to first ephyra release decreased with longer winter
\end{abstract}

Handling editor: Iacopo Bertocci

Electronic supplementary material The online version of this article (https://doi.org/10.1007/s10750-020-04483-9) contains supplementary material, which is available to authorised users.

A. Loveridge $(\bowtie) \cdot$ C. H. Lucas

Ocean and Earth Science, University of Southampton, Southampton, UK

e-mail: al2g14@soton.ac.uk

K. A. Pitt

Australian Rivers Institute - Coasts and Estuaries, Griffith School of Environment and Science, Griffith University, Gold Coast, QLD, Australia incubations, and more ephyrae were produced following longer and colder winter simulations. This experiment indicates that $A$. aurita requires a minimum period of cooler temperatures to strobilate, and contradicts claims that jellyfish populations will be more prevalent in warming oceans, specifically in the context of warmer winter conditions. Such investigations on population-specific ontogeny highlights the need to examine each life stage separately as well as in the context of its environment.

Keywords Jellyfish bloom · Polyp · Asexual reproduction $\cdot$ Temperature

\section{Introduction}

Scyphozoan medusae are key components of marine ecosystems (Richardson et al., 2009), providing essential ecosystem services (Doyle et al., 2014; Yusuf et al., 2018) despite their frequent portrayal as trophic dead ends, or in the media as dangerous nuisances (Lunney \& Moon, 2008). Whilst there is still much debate surrounding the extent of the anthropogenic influence on jellyfish population dynamics (Purcell, 2012; Pitt et al., 2018), if present in large numbers jellyfish blooms can cause problems for human coastal services (Lynam et al., 2006; Roux et al., 2013; Remigante et al., 2018). 
One of the most frequent blooming species along the south coast of England is Aurelia aurita (Linnaeus, 1758) (Pikesley et al., 2014; Dawson et al., 2015). Aurelia is a cosmopolitan genus of Scyphozoa (Russell, 1970) comprising multiple cryptic species living in coastal and shelf sea environments between $70^{\circ} \mathrm{N}$ and $40^{\circ} \mathrm{S}$ (Dawson \& Jacobs, 2001). Like many scyphozoans, it has a complex life cycle comprising a pelagic sexual medusa and a benthic asexual polyp (Lucas, 2001; Fuchs et al., 2014). Through the production of ephyrae via strobilation, polyps directly and indirectly influence where medusa populations occur, the seasonal and interannual variability in medusa abundance, and may even be key to the success or failure of a jellyfish bloom (Gröndahl, 1988; Feng et al., 2018; Schnedler-Meyer et al., 2018).

Strobilation in Aurelia aurita has been studied in a variety of populations in the laboratory (Holst, 2012; Fuchs et al., 2014; Sukhoputova \& Kraus, 2017). In situ, most populations strobilate following the seasonal cooling and subsequent warming of the water (Brewer, 1989; Feng et al., 2018), alongside changes in other variables such as salinity (Holst \& Jarms, 2010), light (Custance, 1964, Purcell et al., 2009), oxygen (Condon et al., 2001), tidal rhythms (Calder, 1974) and food supply (Lucas \& Williams, 1994). Different polyp populations vary widely in their response to forcing variables and authors have suggested varied and sometimes contradicting triggers (Sukhoptova \& Kraus, 2017). For example, in many temperate locations ephyrae are typically released in spring (Lucas, 1996; Schnedler-Meyer et al., 2018), or following ice-out in late February in the Niantic River, USA (Brewer, 1989). However, some populations, such as those in the Suez Canal, strobilate when they reach the winter minimum temperature (Hamed \& Khaled, 2011; Sukhoputova \& Kraus, 2017). Others follow tidal rather than temperature cues: in Roscoe Bay, Canada, strobilation occurs in June and July coinciding with the lowest summer tides (Albert \& Walsh, 2014). Finally, in Horsea Lake, UK, from where the current study animals originate, most $A$. aurita ephyrae appear in early spring around February and March (Lucas, 1996).

Despite the range of responses to a number of forcing variables, temperature consistently appears as one of the main triggers of strobilation, although the magnitude and direction of temperature change (i.e. cooling vs. warming) is inconsistent between studies
(Holst, 2012; Treible \& Condon, 2019). Thermal windows constrain polyps' latitudinal distributions, and temperature determines the rate at which physiological processes occur (Gambill \& Peck, 2014; Höhn et al., 2017). The gene CL390 is a temperaturedependent molecular timer that interacts with the RxR transcription factor to distinguish between short-term temperature fluctuations and seasonal changes, regulating the polyp-to-jellyfish transition in Aurelia spp. (Fuchs et al., 2014; Shi et al., 2018). It is produced gradually at low temperatures, initiating metamorphosis once an activation threshold is reached. This results in the initiation of strobilation only after a sufficient period of time at low temperatures (Fuchs et al., 2014). Purcell et al. (2009) showed that Aurelia spp. polyps strobilated earlier when the pre-strobilation temperature was higher. However, a number of other studies propose that a period at colder temperatures is necessary to ensure that ephyral growth and development occurs in spring, when temperate species can take advantage of the spring bloom (Lucas, 2001; Widmer et al., 2016).

Alongside increased food availability, warmer winter periods may promote the production of certain temperate scyphozoan medusae (Purcell et al., 2012; Goldstein \& Steiner, 2020). However, large-scale climatic variability has the potential to modify the timing and abundance of phytoplankton blooms, and to directly change zooplankton community structure (Edwards and Richardson, 2004; Hays et al., 2005). In such regions, certain scyphozoan jellyfish, such as $A$. aurita, can act as indicators of ecosystem variability (Lynam et al., 2004). For example, across the North Atlantic, the North Sea and Europe, the North Atlantic Oscillation (NAO) influences the variability of weather systems, both directly and indirectly affecting marine ecosystems (Beaugrand, 2003). The NAO has a strong positive correlation with sea surface temperature in areas such as the North Sea, where it is at its strongest in spring and winter. This period coincides with A. aurita ephyra release in early spring (Lucas, 2001; Lynam et al., 2004). A strong inverse relationship exists between the winter NAOI and the median abundance of $A$. aurita medusae in this region, suggesting that especially in the winter and spring months, increased sea surface temperatures during high NAOI phases may contribute to poor strobilation and ephyral development, resulting in smaller populations of medusae in the summer (Lynam et al., 
2004). To add to these observations and further elucidate this link between the hydroclimatic environment and A. aurita populations, it is necessary to understand to what extent variable winter temperatures influence A. aurita polyp reproduction.

Despite being mentioned in Treible \& Condon (2019) as a determining factor of the phenology in strobilation, duration of the winter period has not been examined as a factor influencing strobilation in the spring, even though the gene CL390 necessitates a certain period at cooler temperatures to initiate strobilation (Fuchs et al., 2014). To predict the timing and magnitude of ephyra release, it is essential to understand how the conditions preceding strobilation influences a population, from triggering the strobilation process, to the final number of ephyrae produced. Here we report on a laboratory experiment investigating the effects of different winter temperatures and durations on the production of ephyrae by scyphistomae originating from Horsea Lake in the UK. The following hypotheses were tested: differences in the duration and temperature of the winter period would significantly affect (i) the time from the temperature increase to strobilation, (ii) the proportion of polyps strobilating, and (iii) total numbers of ephyrae produced.

\section{Methods}

Establishment of polyp cultures

Polyps of Aurelia aurita were settled from planula larvae taken from three mature female medusae collected from Horsea Lake, UK (50 $49^{\prime} 58.8$; $\left.1^{\circ} 05^{\prime} 36.9\right)$ on $28^{\text {th }}$ June 2018 , when the ambient surface temperature was $23{ }^{\circ} \mathrm{C}$ and the salinity 23.5 (Dawson et al., 2015). Horsea Lake is a brackish, semi-enclosed, man-made body of water connected to Portsmouth Harbour via a controlled pipe and valve, and the bottom $(6 \mathrm{~m})$ water temperature typically ranges from $5.5^{\circ} \mathrm{C}$ in February to $23.0^{\circ} \mathrm{C}$ in July, remaining below $10{ }^{\circ} \mathrm{C}$ from November to March (Lucas, 1996; CEFAS, 2018). The winter minimum usually occurs in February at $7{ }^{\circ} \mathrm{C}$ but has ranged from $10{ }^{\circ} \mathrm{C}$ in 2008 to $3.7^{\circ} \mathrm{C}$ in 1986 (CEFAS, 2018).

Medusae and released larvae that settled into polyps were maintained for 3 months in a kreisel at the National Oceanography Centre Southampton aquarium. Fully developed polyps that settled on the glass surface were removed using a scalpel and Pasteur pipette and reattached by placing polyps directly on the bottom of individual $60 \mathrm{ml}$ clear polystyrene pots filled with water at the same salinity, maintained in darkness. The pots had been preconditioned by filling them with seawater $24 \mathrm{~h}$ before the procedure.

\section{Polyp maintenance}

One hundred and sixty reattached polyps were maintained in individual $60 \mathrm{ml}$ microcosms at $15{ }^{\circ} \mathrm{C}$ for 14 days before the start of the experiment. Any offspring (podocysts, directly and stolonally budded polyps or ephyrae) produced before the start of the experiment were removed using a scalpel and Pasteur pipette after naturally separating from the parent polyp. Over 7 days (sensu Widmer et al., 2016; Treible \& Condon, 2019) replicates were transitioned to experimental temperatures $\left(4^{\circ} \mathrm{C}, 1.5^{\circ} \mathrm{C}\right.$ day ${ }^{-1}$; $7{ }^{\circ} \mathrm{C}, 1.1^{\circ} \mathrm{C}$ day $^{-1} ; 10{ }^{\circ} \mathrm{C}, 0.7^{\circ} \mathrm{C} \mathrm{day}^{-1}$; and $13{ }^{\circ} \mathrm{C}$, $0.2{ }^{\circ} \mathrm{C}$ day ${ }^{-1}$ ).

Salinity was maintained at 23.5 and seawater was completely exchanged once a week. Seawater was sourced from Southampton Water and passed through pressurised sand filters, a UV steriliser, a protein skimmer and a de-nitrifier before use. When required, reduced salinity water was created by adding reverse osmosis water to seawater until the desired salinity was achieved. Food was supplied at non-limiting quantities once a week, directly on to polyp tentacles using a Pasteur pipette to minimise uneaten food remaining in the water. Due to suggestions that Artemia nauplii are not of sufficient quality to sustain polyps (Lesniowsky et al., 2015), a combination of ZM100 (80-200 micron dried zooplankton) mixed with 1-day-old Artemia nauplii were fed to the polyps. Polyp cultures were maintained in darkened temperature controlled incubators apart from when measurements were being taken $(<1 \mathrm{~min})$ or when being fed $(<1 \mathrm{~min})$ to minimise algal growth and to remove any confounding effects of the dark/light cycle on asexual reproduction (Holst \& Jarms, 2007; Liu et al., 2009). Any offspring (podocysts, directly and stolonally budded polyps or ephyrae) produced during the experiment were recorded and removed using a scalpel and Pasteur pipette after naturally separating from the parent polyp. 
Experimental setup

The experiment consisted of two orthogonal factors: temperature (three levels: 4,7 and $10{ }^{\circ} \mathrm{C}$ ) and duration (four levels: 2, 4, 6, 8 weeks; Fig. 1). Controls were maintained at a constant temperature $(4,7,10$ or $13{ }^{\circ} \mathrm{C}$ ) for 12 weeks. Each treatment had 10 replicates, each comprising a single polyp in a $60 \mathrm{ml}$ microcosm. Following each incubation period, all treatments were moved to $13{ }^{\circ} \mathrm{C}$ (average springtime temperature) for 4 weeks. If after 4 weeks there was no evidence of strobilation (i.e. lateral constrictions of the polyp, darkened colour, retraction of tentacles or presence of ephyrae) the treatment was terminated. If any polyps were about to strobilate or were still strobilating then they were maintained at $13{ }^{\circ} \mathrm{C}$ until they released all ephyrae. Controls were not moved to $13{ }^{\circ} \mathrm{C}$ and remained at a constant temperature for 12 weeks to demonstrate that a temperature change is necessary to initiate strobilation. Reproductive output (number of stolonal, directly budded polyps, podocysts, and ephyrae), survival and attachment were recorded weekly.
Temperature cycles in Horsea Lake and Southampton Water are very similar (Lucas et al., 1997), and temperature data from Southampton Water were used because it has longer data records (1984-2012; Fig. 2) revealing more of the interannual variability (CEFAS, 2018).

\section{Data analyses}

No ephyrae were produced in the 2- or 12-week treatments, and only 2 ephyrae were produced in the 4-week treatment so these data were excluded from all following analyses. Time from the end of the winter simulation to first ephyra release was analysed using a two-way ANOVA. The factors were Duration (two levels; 6 and 8 weeks) and Temperature (three levels: 4, 7 and $10{ }^{\circ} \mathrm{C}$ ). As no significant interaction occurred between temperature and duration, the interaction term was removed and an additive analysis was carried out. The number of replicates that strobilated within each treatment was analysed using a logistic regression model (family: binomial; $n=10$ ). As no significant interaction occurred between temperature and

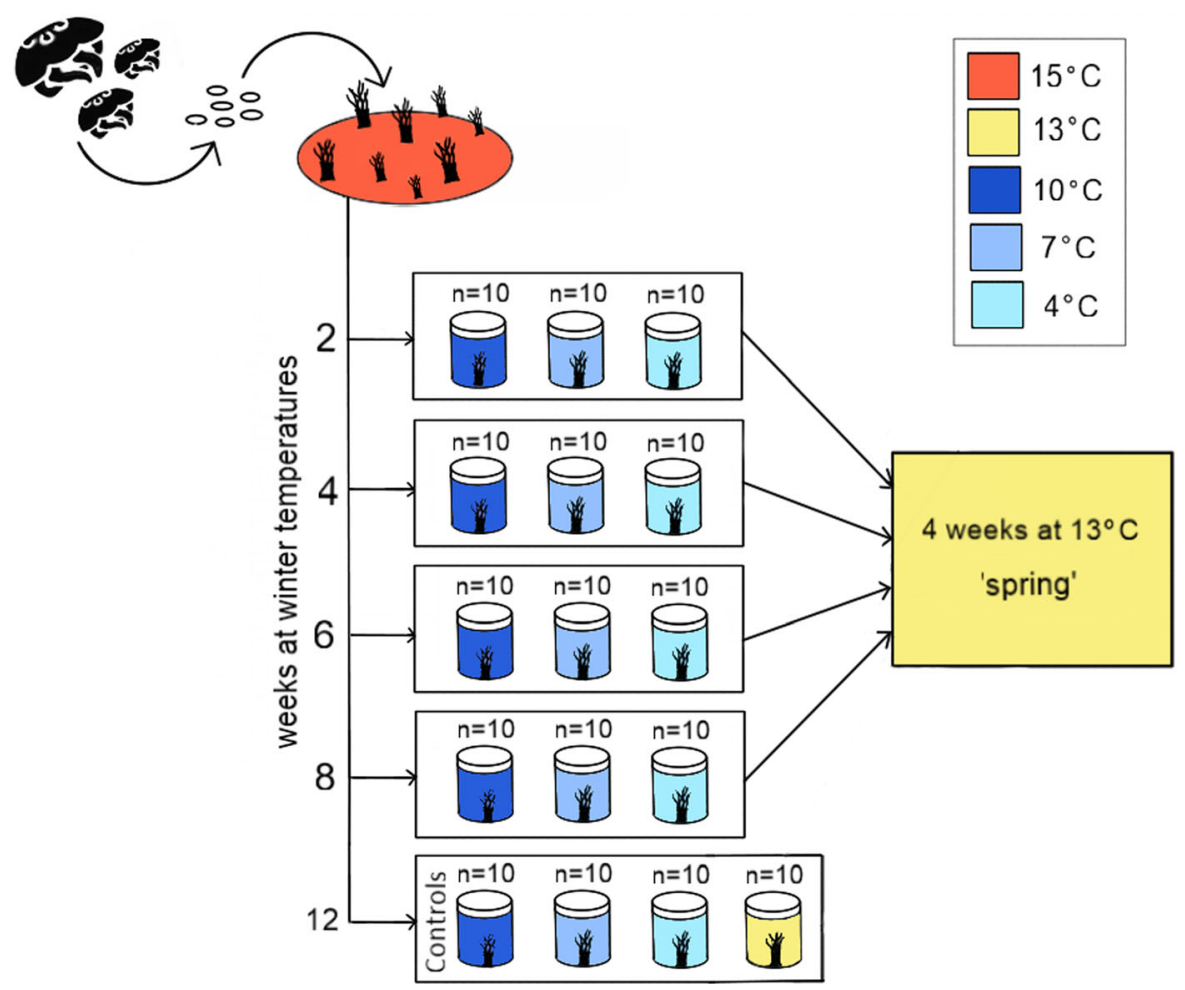

Fig. 1 Experimental design 


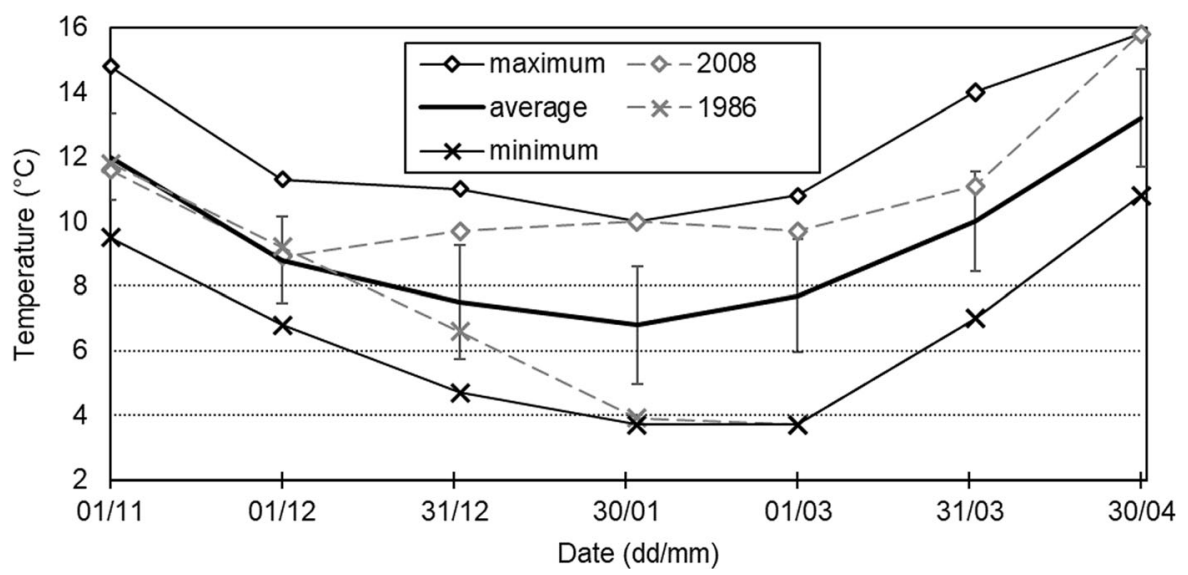

Fig. 2 Average monthly winter sea surface temperature in Southampton Water from November to May 1984-2012. Original data obtained from CEFAS (2018)

duration, the interaction term was removed and an additive analysis was carried out. Post hoc tests were consequently conducted separately within temperature $\left(4,7,10{ }^{\circ} \mathrm{C} ; n=40 /\right.$ temperature $)$ and duration $(2,4,6$, 8 weeks; $n=30 /$ duration) groups. Finally, since the dataset on number of ephyrae produced was zeroinflated, a negative binomial regression model was created to analyse the influence of temperature and duration on the total number of ephyrae produced per replicate $(n=10)$.

Prior to analysis, data were tested for normality (Shapiro-Wilk test) and homogeneity of variance (Bartlett test). If variances could not be stabilised by transformation, $\alpha$ was reduced to 0.01 to reduce the risk of Type I error. Best fitting models were chosen based on Akaike Information Criterion (AIC). When significant differences were detected post hoc multiple comparisons of means (Tukey contrasts) determined which treatments differed.

\section{Results}

Survival and budding

All replicates survived to the end of the experiment except for a single replicate in each of the 4 weeks/ $10{ }^{\circ} \mathrm{C}$ and 8 weeks $/ 4{ }^{\circ} \mathrm{C}$ treatments that died (disintegration of polyp body) before the temperature was increased to $13{ }^{\circ} \mathrm{C}$. Minimal budding and podocyst production was observed in all treatments (See appendices 1-3 for further details).
Days from temperature increase to first ephyrae release

Time to first ephyra release decreased significantly with increasing winter duration, with replicates incubated for 8 weeks at winter temperatures releasing ephyrae on average 10 days earlier than those incubated for 6 weeks (Table 1; Fig. 3). Temperature of incubation did not influence the average number of days to first ephyra release $(P>0.05)$.

\section{Number of replicates strobilating}

More replicates strobilated in treatments incubated at cooler or average winter temperatures (Table 2). Approximately one quarter of replicates incubated at 4 and $7{ }^{\circ} \mathrm{C}$ strobilated, whilst only $4 \%$ strobilated at $10{ }^{\circ} \mathrm{C}$ (Fig. 4a). Duration also affected the number of replicates that strobilated (Table 2), with more than 5 times as many polyps strobilating when incubated at winter temperatures for eight weeks than for 4 weeks (Fig. 4b).

Table 1 Two-way ANOVA model results comparing the number of days to first ephyra release between treatments

\begin{tabular}{llllr}
\hline Day to first ephyra release & Mean Sq & df & $F$ & $P$ value \\
\hline Duration & 0.759 & 1 & 15.404 & $<\mathbf{0 . 0 0 1}$ \\
Temperature & 0.066 & 1 & 1.348 & 0.259 \\
\hline
\end{tabular}

Values in bold are significant at $P<0.05$. df $=$ degrees of freedom 


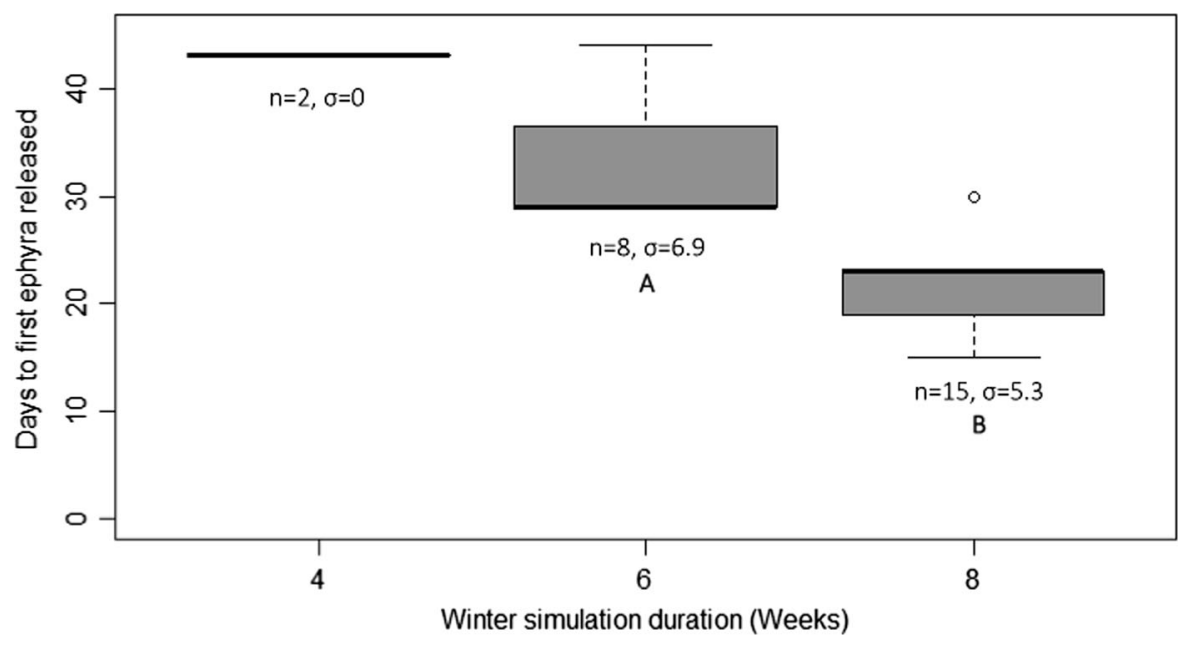

Fig. 3 Number of days from the end of the winter simulation to first ephyra release. Only replicates that produced at least one ephyra are included. A bold line inside each box and whisker plot marks the median. The extremities of the box denote the first and the third quartile and the dotted lines denote the range.
Any points beyond the dotted line are outliers. Letters below each box indicates differences (e.g. A, B) between treatments, as determined by post hoc tests. Note the 4 -week treatment was excluded from the analysis

Table 2 Logistic regression model (family = binomial) test results comparing the influence of duration and temperature on the number of replicates strobilating within each treatment

\begin{tabular}{lcrr}
\hline$\%$ replicates strobilating within each treatment & Estimate & SE & $P$ value \\
\hline Duration & 0.778 & 0.178 & $<\mathbf{0 . 0 0 1}$ \\
Temperature & -0.378 & 0.125 & $\mathbf{0 . 0 0 2}$ \\
\hline
\end{tabular}

Values in bold are significant at $P<0.05$. df $=$ degrees of freedom

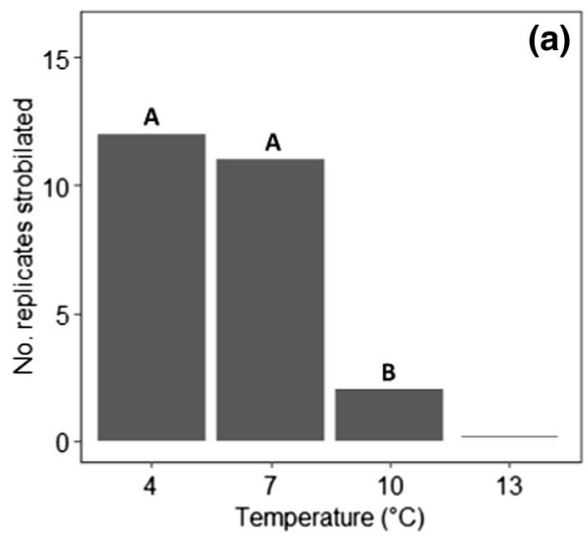

Fig. 4 Number of replicates that strobilated at each (a) temperature and (b) duration. The two graphs refer to separate groupings and contain 120 experimental replicates and 40 control replicates, giving a total of 160 replicates each. Letters

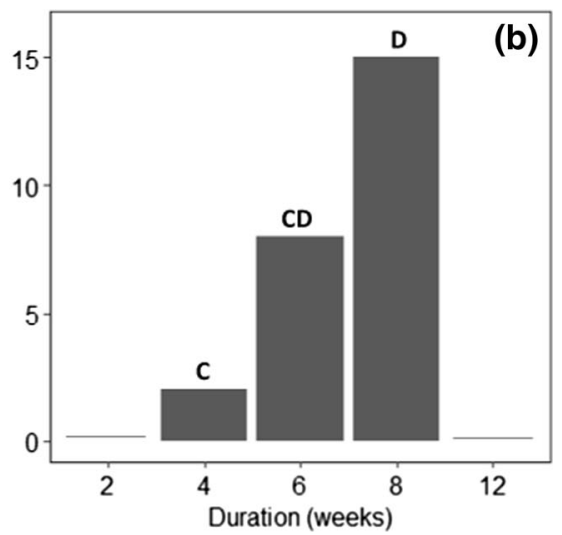

above data points indicate similarities (e.g. A, A) and differences (e.g. A, B) between treatments, as determined by post hoc tests 
Ephyra production

The number of ephyrae produced varied among duration treatments, but patterns differed depending on the temperature at which polyps were incubated (Table 3). For example, in the 6-week treatments more ephyrae were produced when incubated at cold or average temperatures, whereas those incubated at $10{ }^{\circ} \mathrm{C}$ only produced ephyrae when incubated for 8 weeks (Fig. 5). The most ephyrae were produced in the 8-week treatment when incubated at $7{ }^{\circ} \mathrm{C}$ (with a maximum of 21 ephyrae produced by a single polyp).

\section{Discussion}

How changes in sea surface temperature may influence marine organisms, especially ectotherms (Pinsky et al., 2019) such as fishes (Moyano et al. 2017; Dahlke et al., 2020) and zooplankton (Edwards and Richardson, 2004; Kvile et al., 2016), has been one of the key focuses of research efforts over the past two decades. Whilst numerous studies have now examined temperature effects on jellyfish and especially on polyps (Shi et al., 2018; Purcell et al., 2012; Lu et al., 2020), none have examined potential interactions between temperature and duration of temperature on strobilation. Within this context, we show for the first time how the temperature and duration of the winter period influences reproduction in the spring. Polyps were more productive (i.e. more polyps strobilated and more ephyrae were produced) when incubated for longer periods of time at cold $\left(4^{\circ} \mathrm{C}\right)$ and average $\left(7^{\circ} \mathrm{C}\right)$ winter temperatures. Furthermore, polyps began strobilating sooner following longer ( 8 week) incubations. Consequently, the shorter, warmer winters predicted under climate change (IPCC, 2013, 2018) are likely to produce fewer ephyrae and, potentially, to lead to smaller populations of medusae in temperate coastal regions. In the shortest incubation (2 weeks), no polyps strobilated and very few of those incubated at the warmest temperature $\left(10^{\circ} \mathrm{C}\right)$ strobilated and only when incubated for 8 weeks. This indicates that polyps are likely to have a limited thermal window in which they can successfully strobilate.

Thermal windows constrain ectothermic animal distributions and limit the geographic range within which they can live and reproduce (Höhn et al., 2017; Dahlke et al., 2020). Each population's thermal window differs and this may contribute to the population-specific timings of reproduction, and to their variable responses to different minimum winter temperatures (Kroiher et al., 2000; Pascual et al., 2015; Kvile et al., 2016). Some studies report that warmer temperatures result in more ephyrae (e.g. Holst, 2012) and others report that cooler temperatures increase productivity (e.g. Kroiher et al., 2000; Purcell et al., 2012; Widmer et al., 2016). Such inconsistencies may exist because the Aurelia genus is highly plastic and the species Aurelia aurita comprises numerous cryptic species (Dawson et al., 2015). Our results from Horsea Lake on the south coast of the UK provide evidence that cooler winter temperatures could enhance strobilation in temperate populations of A. aurita polyps.

Interannual variations in timing of strobilation result partly from differences in winter duration and temperature. In the laboratory, the 'preconditioning period', experienced by polyps prior to the induction of strobilation, mimics this preparatory period and influences how polyps respond to cues. Differences in preconditioning between experiments may explain variations in response time and production of ephyrae between these studies (Kroiher et al., 2000; Purcell et al., 2012; Fuchs et al., 2014). However, due to large differences in experimental setups and procedures, separating this influence from other environmental

Table 3 Negative binomial regression model results comparing the total number of ephyrae produced per polyp between treatments $(n=10)$

\begin{tabular}{lcll}
\hline Total ephyrae produced per polyp & Estimate & SE & $P$ value \\
\hline Duration & -1.291 & 0.914 & 0.158 \\
Temperature & -2.323 & 0.934 & $\mathbf{0 . 0 1 3}$ \\
Duration:Temperature & 0.277 & 0.129 & $\mathbf{0 . 0 3 2}$ \\
\hline
\end{tabular}

Values in bold are significant at $P<0.05$. df $=$ degrees of freedom 


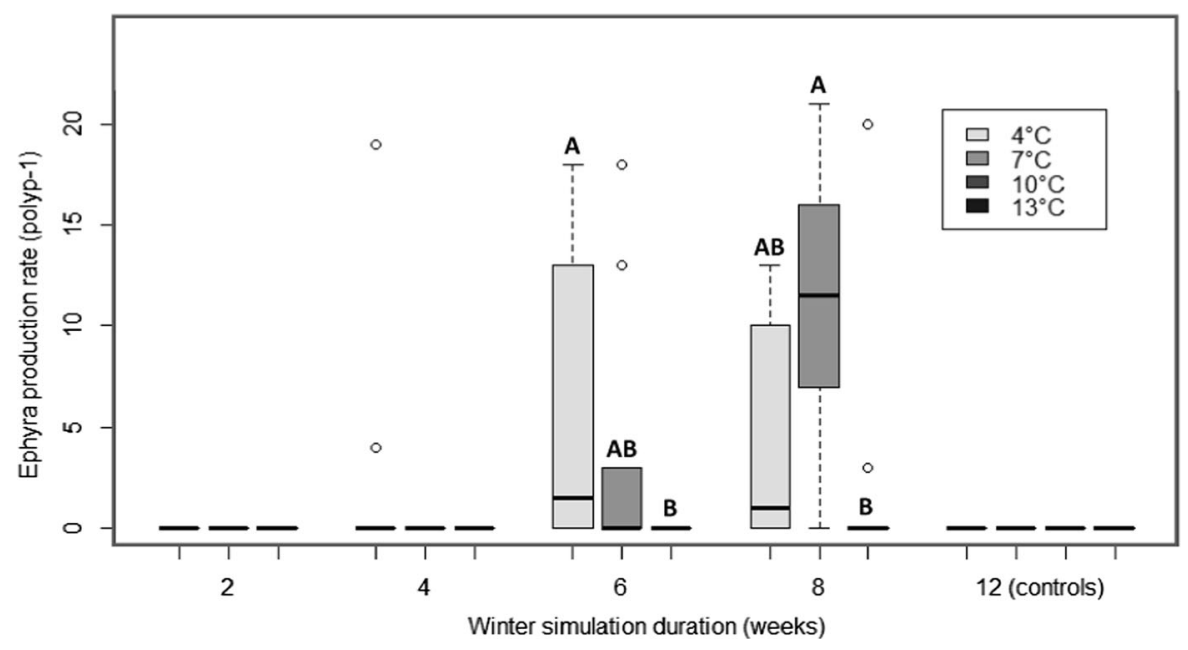

Fig. 5 Median number of ephyrae produced per polyp in each treatment ( $n=10$ replicates/treatment). A bold line inside each box and whisker plot marks the median. The extremities of the box denote the first and the third quartile and the dotted lines

factors in past studies is very challenging (Hubot et al., 2017). In situ, the trend of delayed ephyrae appearance after cold winters observed in Southampton Water by Lucas (2001) can be partly explained by the duration of the winter period and, in particular, the timing of the winter minimum. Shorter, sharper winters, whilst increasing the final number of ephyrae produced, may delay their production as compared to longer winters where ephyrae respond more rapidly to the eventual warming of the water in the spring.

A key finding of our study was that minimal strobilation was observed following incubation at warmer-than-average winter temperatures. The interaction of the RxR transcription factor and the Aurelia spp. specific protein CL390, a likely candidate for the strobilation hormone, provides insight into the molecular processes behind the lack of strobilation in the warmer treatments (Fuchs et al., 2014). Specifically, the above-average winter temperature may not have reached the critical low threshold needed to induce upregulation of the CL390 transcript. Alternatively, a longer incubation at these temperatures was needed to produce enough transcript to reach the activation threshold and initiate strobilation. This lack of strobilation has been observed in other experiments on temperate species, where temperatures were suggested to be too high to induce ephyra production (Willcox et al., 2007). This effect is compounded when examining temperature and duration combined. denote the range. Points beyond the dotted line are outliers. Letters indicate similarities (e.g. A, A) and differences (e.g. A, B) between temperature treatments within each duration, as determined by post hoc tests

Differences in the response to spring warming between the shorter (2, 4 weeks), and the longer winter incubations $(6,8$ weeks) in the current experiment may represent the difference between the response to a short-term cold snap, and a seasonal change. In North Sea regions, such as along the French Normandy coast, polyps needed at least 15 days at colder temperatures when moved from 20 to $15^{\circ} \mathrm{C}$, and 9 days when moved from 18 to $10{ }^{\circ} \mathrm{C}$ to initiate strobilation (Kroiher et al., 2000). In Horsea Lake polyps, a longer winter incubation resulted in strobilation occurring more rapidly and in more polyps producing more ephyrae following the shift to spring temperatures. To initiate significant strobilation, polyps need to be incubated at an average or coolerthan-average temperature for this region for about 6 weeks.

Most studies examining temperature effects on scyphozoan jellyfish have proposed that moderately warmer temperatures benefit temperate jellyfish populations, by enhancing ephyral growth and reproduction in polyps and medusae (e.g. Purcell, 2005; Widmer, 2005). These studies have focussed on the warmer (summer) temperature threshold. Warmer winter temperatures in temperate regions such as the North Sea, however, are likely to inhibit spring jellyfish blooms, as proposed by Lynam et al. (2004). The current study indicates that winters exceeding 6 weeks and $<7{ }^{\circ} \mathrm{C}$ are likely to result in 
larger temperate Aurelia populations, whereas years that experience a warmer and shorter-than-average winter may experience reduced or delayed strobilation. However, it is still unclear whether induction of strobilation occurs due to reaching a critical temperature threshold (e.g. winter minimum) or a relative change in temperature, and it would be beneficial to understand how consistent these results are between different populations.

This study has important implications in the current climate of global warming, where some regions are experiencing rapid warming and increasing winter temperatures (Belkin, 2009). For example, enclosed and semi-enclosed European seas such as the Baltic and North Seas have experienced rapid warming from 1982 to 2006, with the Baltic Sea warming at a rate of $1{ }^{\circ} \mathrm{C}$ per decade (Belkin, 2009). Holst (2012) posited that increasing sea temperatures might benefit $A$. aurita polyps from the North Sea. This study shows that polyps from Horsea Lake, UK, are unlikely to strobilate after experiencing warmer-than-average winter temperatures. In future scenarios of climate warming, temperate polyps are likely to experience shorter, warmer winter periods that may not always reach the long-term average winter minimum. Whilst there are many confounding factors that drive jellyfish population cycles and the appearance of blooms (Brodeur et al., 2008; Lynam et al., 2011), if polyps no longer experience the cues to initiate strobilation, then they are unlikely to produce ephyrae, preventing future bloom formation (Fuchs et al., 2014; Treible \& Condon, 2019). Despite evidence that some local populations may be able to adapt to changing environmental conditions (Lu et al., In press), recent warming may be too fast for these species to respond to (IPCC, 2018). Future investigations should focus on this crucial preconditioning period by studying each life stage in isolation and in combination with others, to predict how changing conditions will affect jellyfish populations in the future.

Acknowledgements This research was supported by the University of Southampton, and was carried out through the NERC-funded SPITFIRE Doctoral Training Partnership. We want to thank Robbie Robinson and George Clarke for technical assistance throughout the study.

Funding This work was supported by the Natural Environmental Research Council [Grant No. NE/L002531/1].
Data availability The datasets generated during and/or analysed during the current study are available from the corresponding author on reasonable request.

\section{Compliance with ethical standards}

Conflict of interest The authors have declared that no competing interests exist.

Ethical approval The moon jellyfish Aurelia aurita is not a protected species in the area of study. Permission was obtained from the Royal Navy to access Horsea Lake, UK $\left(50^{\circ} 49^{\prime} 58.8\right.$; $\left.1^{\circ} 05^{\prime} 36.9\right)$ to collect $A$. aurita specimens. All international, national, and/or institutional guidelines for the care and use of animals were followed where applicable.

Open Access This article is licensed under a Creative Commons Attribution 4.0 International License, which permits use, sharing, adaptation, distribution and reproduction in any medium or format, as long as you give appropriate credit to the original author(s) and the source, provide a link to the Creative Commons licence, and indicate if changes were made. The images or other third party material in this article are included in the article's Creative Commons licence, unless indicated otherwise in a credit line to the material. If material is not included in the article's Creative Commons licence and your intended use is not permitted by statutory regulation or exceeds the permitted use, you will need to obtain permission directly from the copyright holder. To view a copy of this licence, visit http://creativecommons.org/licenses/by/4.0/.

\section{References}

Albert, D. J. \& M. L. Walsh, 2014. Aurelia labiata jellyfish in Roscoe Bay on the West Coast of Canada: seasonal changes in adult bell diameter and mingling of juvenile and adult populations. Journal of Sea Research 85: 178-185.

Beaugrand, G., 2003. Long-term changes in copepod abundance and diversity in the north-east Atlantic in relation to fluctuations in the hydroclimatic environment. Fisheries Oceanography. 12: 270-283.

Belkin, I. M., 2009. Rapid warming of Large Marine Ecosystems. Progress in Oceanography 81: 207-213.

Brewer, R. H., 1989. The annual pattern of feeding, growth and sexual reproduction in Cyanea (Cnidaria: Scyphozoa) in the Niantic River Estuary, Connecticut. Biological Bulletin 176: 272-281.

Brodeur, R. D., M. B. Decker, L. Ciannelli, J. E. Purcell, N. A. Bond, P. J. Stabeno, E. Acuña \& G. L. Hunt Jr., 2008. Rise and fall of jellyfish in the eastern Bering Sea in relation to climate regime shifts. Progress in Oceanography 77: 103-111.

Calder, D. R., 1974. Strobilation of the Sea Nettle, Chrysaora quinquecirrha, under field conditions. Biological Bulletin 146(3): 326-334.

CEFAS, 2018. Station 22: Fawley PS. In. https://www.cefas.co. uk/cefas-data-hub/sea-temperature-and-salinity-trends/ 
presentation-of-results/station-22-fawley-ps/ Accessed 16 August 20182018.

Condon, R. H., M. B. Decker \& J. E. Purcell, 2001. Effects of low dissolved oxygen on survival and asexual reproduction of scyphozoan polyps (Chrysaora quinquecirrha). Hydrobiologia 451: 89-95.

Custance, D. R. N., 1964. Light as an inhibitor of strobilation in Aurelia aurita. Nature 204: 1219-1220.

Dahlke, F. T., S. Wohlrab, M. Butzin \& H.-O. Pörtner, 2020. Thermal bottlenecks in the life cycle define climate vulnerability of fish. Science 369(6499): 65-70.

Dawson, M. N., K. Cieciel, M. B. Decker, G. C. Hays, C. H. Lucas \& K. A. Pitt, 2015. Population-level perspectives on global change: genetic and demographic analyses indicate various scales, timing, and causes of scyphozoan jellyfish blooms. Biological Invasions 17: 851-867.

Dawson, M. N. \& D. K. Jacobs, 2001. Molecular evidence for cryptic species of Aurelia aurita (Cnidaria, Scyphozoa). Biological Bulletin 200: 92-96.

Doyle, T. K., G. C. Hays, C. Harrod \& J. D. R. Houghton, 2014. Ecological and Societal Benefits of Jellyfish. In Pitt, K. A. \& C. H. Lucas (eds.), Jellyfish Blooms. Springer, Dordrecht: 105-127.

Edwards, M. \& A. J. Richardson, 2004. Impact of climate change on marine pelagic phenology and trophic mismatch. Nature 430: 881-884.

Feng, S., S. Wang, S. Sun, F. Zhang, G. Zhang, M. Liu \& S. Uye, 2018. Strobilation of three scyphozoans (Aurelia coelurea, Nemopilema nomurai, and Rhopilema esculentum) in the field at Jiaozhou Bay, China. Marine Ecology Progress Series 591: 141-153.

Fuchs, B., W. Wang, S. Graspeuntner, Y. Li, S. Insua, E. M. Herbst, P. Dirksen, A. M. Böhm, G. Hemmrich, F. Sommer, T. Domazet-Lošo, U. C. Klostermeier, F. AntonErxleben, P. Rosenstiel, T. C. G. Bosch \& K. Khalturin, 2014. Regulation of Polyp-to-Jellyfish Transition in Aurelia aurita. Current Biology 24(3): 263-273.

Gambill, M. \& M. A. Peck, 2014. Respiration rates of the polyps of four jellyfish species: potential thermal triggers and limits. Journal of Experimental Marine Biology and Ecology 459: 17-22.

Goldstein, J. \& U. K. Steiner, 2020. Ecological drivers of jellyfish blooms: the complex life history of a 'well-known' medusa (Aurelia aurita). Journal of Animal Ecology. https://doi.org/10.1111/1365-2656.13147.

Gröndahl, F., 1988. A comparative ecological study on the scyphozoans Aurelia aurita, Cyanea capillata and $C$. lamarckii in the Gullmar Fjord, western Sweden, 1982 to 1986. Marine Biology 97: 541-550.

Hamed, A. E. \& A. A. Khaled, 2011. Reproductive strategy of the jellyfish Aurelia aurita (Cnidaria Scyphomedusae) in the Suez Canal and its migration between the Red Sea and Mediterranean. Aquatic Ecosystem Health \& Management 14(3): 269-275.

Hays, G. C., A. J. Richardson \& C. Robinson, 2005. Climate change and marine plankton. Trends in Ecology and Evolution 20(6): 337-344.

Höhn, P. H., C. H. Lucas \& S. Thatje, 2017. Respiratory response to temperature of three populations of Aurelia aurita polyps in Northern Europe. PLoS ONE 12(5): 1-13.
Holst, S., 2012. Effects of climate warming on strobilation and ephyra production of North Sea scyphozoan jellyfish. Hydrobiologia 690: 127-140.

Holst, S. \& G. Jarms, 2007. Substrate choice and settlement preferences of planula larvae of five Schyphozoa (Cnidaria) from German Bight, North Sea. Marine Biology 151: $863-871$.

Holst, S. \& G. Jarms, 2010. Effects of low salinity on settlement and strobilation of Scyphozoa (Cnidaria): is the lion's mane Cyanea capillata (L.) able to reproduce in the brackish Baltic Sea? Hydrobiologia 645: 53-68.

Hubot, N., C. H. Lucas \& S. Piraino, 2017. Environmental control of asexual reproduction and somatic growth of Aurelia spp (Cnidaria, Scyphozoa) polyps from the Adriatic Sea. PLoS ONE 12: 6.

IPCC, 2013. Climate Change 2013: The Physical Science Basis. Contribution of Working Group I to the Fifth Assessment Report of the Intergovernmental Panel on Climate Change. Stocker T. F., D. Qin, G.-K. Plattner, M. Tignor, S. K. Allen, J. Boschung, A. Nauels, Y. Xia, V. Bex, P.M. Midgley (eds.) Cambridge University Press, Cambridge. pp. 1535.

IPCC, 2018. Global Warming of $1.5^{\circ} \mathrm{C}$. An IPCC Special Report on the impacts of global warming of $1.5^{\circ} \mathrm{C}$ above pre-industrial levels and related global greenhouse gas emission pathways, in the context of strengthening the global response to the threat of climate change, sustainable development, and efforts to eradicate poverty. MassonDelmotte, V., P. Zhai, H.-O. Pörtner, D. Roberts, J. Skea, P.R. Shukla, A. Pirani, W. Moufouma-Okia, C. Péan, R. Pidcock, S. Connors, J.B.R. Matthews, Y. Chen, X. Zhou, M.I. Gomis, E. Lonnoy, T. Maycock, M. Tignor, and T. Waterfield (eds.). In Press.

Lu, Y., C. H. Lucas \& A. Loveridge, 2020. Transgenerational acclimation influences asexual reproduction in Aurelia aurita jellyfish polyps in response to temperature. Mar Ecol Progr Ser. https://doi.org/10.3354/meps13517.

Kroiher, M., B. Siefker \& S. Berking, 2000. Induction of segmentation in polyps of Aurelia aurita (Scyphozoa, Cnidaria) into medusa and formation or mirror-image medusa anlagen. International Journal of Developmental Biology 44: 485-490.

Kvile, K. Ø., Ø. Langangen, I. Prokopchuk, N. C. Stenseth \& L. C. Stige, 2016. Mechanisms behind climate effects on zooplankton. Proceedings of the National Academy of Sciences 113(7): 1841-1846.

Lesniowski, T. J., M. Gambill, S. Holst, M. A. Peck, M. Algueró-Muñiz, M. Haunost, A. M. Malzahn \& M. Boersma, 2015. Effects of food and $\mathrm{CO}_{2}$ on growth dynamics of polyps of two scyphozoan species (Cyanea capillata and Chrysaora hysoscella). Marine Biology 162: 1371-1382.

Liu, W. C., W. T. Lo, J. E. Purcell \& H. H. Chang, 2009. Effects of temperature and light intensity on asexual reproduction of the scyphozoan, Aurelia aurita (L.) in Taiwan. Hydrobiologia 616: 247-258.

Lucas, C. H., 1996. Population dynamics of Aurelia aurita (Scyphozoa) from an isolated brackish lake, with particular reference to sexual reproduction. Journal of Plankton Research 18(6): 987-1007. 
Lucas, C. H., 2001. Reproduction and life history strategies of the common jellyfish, Aurelia aurita, in relation to its ambient environment. Hydrobiologia 451: 229-246.

Lucas, C. H., A. G. Hirst \& J. A. Williams, 1997. Plankton dynamics and Aurelia aurita production in two contrasting ecosystems: comparisons and consequences. Estuarine, Coastal and Shelf Science 45: 209-219.

Lucas, C. H. \& J. A. Williams, 1994. Population dynamics of the scyphomedusa Aurelia aurita in Southampton Water. Journal of Plankton Research 16(7): 879-895.

Lunney, D. \& C. Moon, 2008. The portrayal of human-wildlife interactions in the print media. In Meikle, W. (ed.), Too close for comfort: contentious issues in human-wildlife encounters, Vol. 34. Royal Zoological Society of New South Wales, New South Wales: 52-64.

Lynam, C. P., M. J. Gibbons, B. E. Axelson, C. A. Sparks, J. Coetzee, B. G. Heywood \& A. S. Brierly, 2006. Jellyfish overtake fish in a heavily fished ecosystem. Current Biology 16(13): 492.

Lynam, C. P., S. J. Hay \& A. S. Brierley, 2004. Interannual variability in abundance of North Sea jellyfish and links to the North Atlantic Oscillation. Limnology and Oceanography 49(3): 637-643.

Lynam, C. P., M. K. S. Lilley, T. Bastian, T. K. Doyle, S. E. Beggs \& G. C. Hays, 2011. Have jellyfish in the Irish Sea benefited from climate change and overfishing? Global Change Biology 17: 767-782.

Moyano, M., C. Candebat, Y. Ruhbaum, S. Álvarez-Fernández, G. Claireaux, J.-L. Zambonino-Infante \& M. A. Peck, 2017. Effects of warming rate, acclimation temperature and ontogeny on the critical thermal maximum of temperate marine fish larvae. PLoS ONE 12(7): e0179928.

Pascual, M., V. Fuentes, A. Canepa, D. Atienza, J.-M. Gili \& J. E. Purcell, 2015. Temperature effects on asexual reproduction of the scyphozoan Aurelia aurita s. 1.: differences between exotic (Baltic and Red seas) and native (Mediterranean Sea) populations. Marine Ecology 36(4): 994-1002.

Piksley, S. K., B. J. Godley, S. Ranger, P. B. Richardson \& M. J. WItt, 2014. Cnidaria in UK coastal waters: description of spatio-temporal patterns and inter-annual variability. Journal of the Marine Biological Association of the United Kingdom 94(7): 1401-1408.

Pinsky, M. L., A. M. Eikeset, D. J. McCauley, J. L. Payne \& J. M. Sunday, 2019. Greater vulnerability to warming of marine versus terrestrial ectotherms. Nature 569: 108-111.

Pitt, K. A., C. H. Lucas, R. H. Condon, C. M. Duarte \& B. Stewart-Koster, 2018. Claims that anthropogenic stressors facilitate jellyfish blooms have been amplified beyond the available evidence: a systematic review. Frontiers in Marine Science 5: 451.

Purcell, J. E., 2005. Climate effects on formation of jellyfish blooms: a review. Journal of the Marine Biological Association of the United Kingdom 85: 461-476.

Purcell, J. E., 2012. Jellyfish and ctenophore blooms coincide with human proliferations and environmental pertubations. Annual Review of Marine Science 4: 209-235.

Purcell, J. E., D. Atienza, V. Fuentes, A. Olariaga, U. Tilves, C. Colahan \& J.-M. Gili, 2012. Temperature effects on asexual reproduction rates of scyphozoan species from the northwest Mediterranean Sea. Hydrobiologia 690: 169-180.

Purcell, J. E., R. A. Hoover \& N. T. Schwark, 2009. Interannual variation of strobilation by the scyphozoan Aurelia labiata in relation to polyp density, temperature, salinity, and light conditions in situ. Marine Ecology Progress Series 375: 139-149.

Remigante, A., R. Costa, R. Morabito, G. La Spada, A. Marino \& S. Dossena, 2018. Impact of scyphozoan venoms on human health and current first aid options for stings. Toxins 10(4): 133.

Richardson, A. J., A. Bakun, G. C. Hays \& M. J. Gibbons, 2009. The jellyfish joyride: causes, consequences and management responses to a more gelatinous future. Trends in Ecology and Evolution 24(6): 312-322.

Roux, J.-P., C. D. van der Lingen, M. J. Gibbons, N. E. Moroff, L. J. Shannon, A. D. M. Smith \& P. M. Cury, 2013. Jellyfication of marine ecosystems as a likely consequence of overfishing small pelagic fishes: lessons from the Benguela. Bulletin of Marine Science 89(1): 249-284.

Russell, F. S., 1970. The Medusa of the British Isles. Volume II: Pelagic Schyphozoa, with a Supplement to the First Volume on Hydromedusae. Cambridge University Press, Great Britain.

Schnedler-Meyer, N. A., T. Kiørboe \& P. Mariani, 2018. Boom and Bust: life History, Environmental Noise, and the (un)Predictability of Jellyfish Blooms. Frontiers in Marine Science 5: 257.

Shi, Y., Z. Yu, Y. Zhen, G. Wang, X. Wang \& T. Mi, 2018. Effect of decreasing temperature on the strobilation of Aurelia sp. 1. Journal of Oceanology and Limnology 36(2): 465-472.

Sukhoputova, A. V. \& Y. A. Kraus, 2017. Environmental factors inducing the transformation of polyp into medusae in Aurelia aurita (Scyphozoa). Russian Journal of Developmental Biology 48(2): 106-116.

Treible, L. M. \& R. H. Condon, 2019. Temperature-driven asexual reproduction and strobilation in three scyphozoan jellyfish polyps. Journal of Experimental Marine Biology and Ecology 520: 151204.

Widmer, C., C. Fox \& A. Brierley, 2016. Effects of temperature and salinity on four species of northeastern Atlantic scyphistomae (Cnidaria: Scyphozoa). Marine Ecology Progress Series 559: 73-88.

Widmer, C. L., 2005. Effects of temperature on growth of northeast Pacific moon jellyfish ephyrae, Aurelia labiata (Cnidaria: Scyphozoa). Journal of the Marine Biological Association of the United Kingdom 85(3): 569-573.

Willcox, S., N. A. Moltschaniwiskyj \& C. Crawford, 2007. Asexual reproduction in scyphistomae of Aurelia sp.: effects of temperature and salinity in an experimental study. Journal of Experimental Marine Biology and Ecology 353: 107-114.

Yusuf, S., I. M. Fahmid, N. Abdullah \& Zulhaeriah, 2018. Indonesian jellyfish as potential for raw materials of food and drug. IOP Conference Series: Earth and Environmental Science 157(1): 012056.

Publisher's Note Springer Nature remains neutral with regard to jurisdictional claims in published maps and institutional affiliations. 